\title{
Value Capture and Policy Design in a Digital Economy
}

\author{
Dan Breznitz • Martin Kenney • Petri Rouvinen • \\ John Zysman • Pekka Ylä-Anttila
}

Received: 31 January 2011 /Revised: 8 April 2011

Accepted: 1 May 2011 / Published online: 31 May 2011

(C) The Author(s) 2011. This article is published with open access at Springerlink.com

\begin{abstract}
Pervasive information and communication technology (ICT), intertwined with global dispersion of supply chains, is inducing a sizable structural transformation. All the articles in this special issue highlight that even though technology is the key driver, the reactions of businesses and countries to these transformations will depend on economic, political, and social arrangements within each organization and society. The competitive landscape of the ICT industry itself is likely to remain in flux. Also in other industries, both value creation and value capture are becoming increasingly complex - and remain more favorable for the developed countries than some commonly used measures suggest. According to the prevailing economic thinking, public policies should set market-friendly "rules of the game" and then stay out of the way. In the ICT domain, technical standards, spectrum allocations, and market power associated with various types of lock-ins play crucial roles calling for more active public involvement. In particular, the dynamic aspects of competition and anti-trust policies are important yet complex. While there is limited
\end{abstract}

D. Breznitz

Sam Nunn School of International Affairs, The Georgia Institute of Technology, 781 Marietta Street, NW, Room 151, Atlanta, GA 30332, USA

e-mail: tbvb@gatech.edu

M. Kenney

Department of Human and Community Development, University of California, Davis, One Shields Avenue, Davis, CA 95616, USA

e-mail: mfkenney@ucdavis.edu

P. Rouvinen $(\square) \cdot$ P. Ylä-Anttila

ETLA, The Research Institute of the Finnish Economy, Lönnrotinkatu 4 B, 00120 Helsinki, Finland e-mail: petri.rouvinen@etla.fi

P. Ylä-Anttila

e-mail: pekka.yla-anttila@etla.fi

J. Zysman

Berkeley Roundtable on the International Economy (BRIE), University of California, Berkeley, 2234

Piedmont Ave, Berkeley, CA 94720, USA

e-mail: zysman@berkeley.edu 
scope for sectoral or horizontal industrial policies, this special issue provides alternative avenues for considering matrix or systemic policies emphasizing education, openness, and national competitiveness.

Keywords ICT $\cdot$ technology $\cdot$ globalization $\cdot$ structural change $\cdot$ industrial policy

JEL Classification $\mathrm{L} 10 \cdot \mathrm{L} 50 \cdot \mathrm{L} 63 \cdot \mathrm{O} 33$

\section{Understanding the structural transformation}

Although digital forms of information and communication technology (ICT) have been commercially available for more than 50 years, we are only now beginning to see their full impact. ICT is causing a similar re-structuring of industries, businesses, and institutions in a way similar to the previous major general purpose technologies, namely steam and electricity (Jovanovic and Rousseau 2005; Helpman 1998; Crafts 2004).

This special issue is an effort to extend our current understanding of the ICT-enabled and ICT-driven structural transformation. This special issue will consider how ICT and its applications are changing and re-shaping the future prospects of businesses and countries. The articles shed light on important—but, as yet poorly understood-aspects of the ongoing digital revolution.

ICT is systemic in ways that link its evolution intimately with applicable regulation and policies. Due to the penetrating role ICT has in our professional and private lives, it interacts with all policy domains. This special issue demonstrates recent changes in globalization and technology that are not adequately reflected in current policies; our attempt is to initiate a debate on what might be the most appropriate future policies in various contexts.

\section{Contributions in this special issue}

In the current re-orientation of ICT, storage and processing are once again being pushed back into huge data centers and away from the terminals of end-users. Kushida et al. (2011) provide conceptual tools to understand cloud computing, which is rapidly emerging as the key platform of the digital age. "The Cloud" deepens specialization among economic actors and increases efficiency in ICT utilization. Perhaps more importantly, the Cloud is (potentially) an engine of innovation and entrepreneurship. By its very nature, the Cloud transcends national boundaries. Therefore its adaption and operation poses considerable policy challenges.

Access to various forms of digitally coded information, which has been stored and processed in the Cloud, increasingly takes place via ubiquitous mobile devices. Concurrently, previous industry boundaries are being drastically altered. Kenney and Pon (2011) note that the launch of Apple's iPhone re-defined the smartphone and accelerated the convergence of traditional mobile telephony, Internet services, and personal computing into a single, but extremely complicated, industry. For example, Apple, Google, Microsoft, and Nokia are now direct competitors (and sometimes allies). Current incumbents are at constant risk of being roiled by entrants with better value propositions. The case of smartphones also illustrates the elusiveness of value creation and capture: competition also takes place between the layers in the industry "stack", be it Apple's AppStore or Google's 
search advertising. Competitive strategies partly focus on commoditizing competitors' value-capture layers to increase the attractiveness of one's own layer.

One directly ICT-enabled aspect of globalization is known as trade-in-tasks (Grossman and Rossi-Hansberg 2008) or the second unbundling (Baldwin 2006), which refers to the ever-finer geographical dispersion of activities in the provision of goods and services. Supply chains of multinational corporations are starting to resemble sliced carrots. For each slice, managers tirelessly ask the "make or buy" question, which is then followed by "by whom" and "where". ${ }^{1}$ Consequently, outsourcing and off-shoring have become topical issues of political debate worldwide. Ali-Yrkkö et al. (2011) suggest that some of these debates might be misplaced. Their analysis of value capture in the case of the Nokia N95 smartphone suggests that international trade statistics seriously distort the overall picture: For example, China may be the largest high-tech exporter but most of the value generated by global supply chains remains to be captured in the developed countries. This is not to say that globalization could not be a win-win proposition - the game is dynamic and complex, and the optimal strategy ultimately depends on the priorities of each society.

ICT has the potential to induce considerable structural changes at both business and national levels. How these changes unfold greatly depends on social and political factors, which are integrated with the local provision and use of ICT. Kushida (2011) illustrates two important aspects of this integration in the case of the Japanese telecommunications sector. First, upon making national regulatory and technology choices, there is a risk of locking into trajectories that are at odds with international developments. This risk is particularly acute in ICT, where these choices often involve irreversible systemic investments. Second, the Japanese case illustrates how national choices influence multinational corporations, even though these enterprises may be fully aware of their adverse consequences. Kushida's work highlights a difficult policy dilemma: how does one become a pioneer and forerunner while avoiding becoming a leader without followers? In hindsight, it seems that Japan could have benefitted from less regulated forms of competition.

In his cross-national study of the retail sector, Watson (2011) focuses on the political and regulatory aspects of ICT use. There have been common transnational patterns in the transformation of retailing, but there is also significant cross-country variation. National policies shape what is optimal in each context; even in a globalizing world, local societal choices continue to matter. Watson argues that aspects of technology use are, for the most part, not determined by technical features, but rather by social and political rules. To exploit technological opportunities to the fullest, national policies should be geared towards changing these rules accordingly.

\section{Policy implications}

Pervasive and often automated ICT, intertwined with the global dispersion of supply chains, is inducing considerable structural changes. All the articles in this special issue highlight that even though technology is the key driver, the reactions of businesses and countries will depend on economic, political, and social arrangements within each organization and society.

The competitive landscape of the ICT industry itself is likely to remain in flux. Also in other industries, both value creation and value capture are becoming increasingly complex. While corporate-level issues do not always aggregate to the national level, in this case there is a straight forward analogy. Ultimately the question for any nation-state is twofold: How

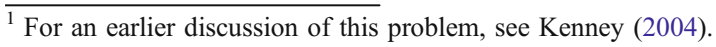


can its citizens have a sufficient volume of high value-added activities in global supply chains? And how can its citizens capture value from those activities? Answering these questions is tricky, not least because both modern information infrastructures and supply chains operate at global scale and with an optimization that transcends national boundaries. Still, national- and regional-level policies influence how the presiding jurisdiction performs both internally and externally.

According the prevailing economic thinking, public policies should set market-friendly "rules of the game" and then stay out of the way. This fantasy is far from an apt description of the world, whether in the financial sector or in the ICT domain, where technical standards, spectrum allocations, and market power, which is often associated with various types of lock-ins, play a crucial role. In particular, the dynamic aspects of competition and anti-trust policies are important but also overwhelmingly complex, especially when lock-ins appear to be almost entirely up to consumer choice (e.g., the decision to use a particular search engine or browser). Within the broader ICT domain, policy issues are found at all levels, from individual citizens' privacy to the regulation of global cloud computing infrastructures or choices by national governments.

With slow growth and high unemployment in most developed countries, "old school" industrial policies have crept back into the policy agenda. With deepening specialization and multi-layered competition, implementing these policies (sensibly) may not only be questionable but also impossible. Instead of sectoral or horizontal industrial policies, there might be some scope for matrix or systemic policies that emphasize education, openness, and the dynamic aspects of national competitiveness (Aiginger 2007). While the current state of our knowledge is insufficient to guide these policies efficiently, this special issue provides alternative avenues for considering of future systemic policies.

Acknowledgements This research is a part of the ongoing collaboration of BRIE, the Berkeley Roundtable on the International Economy at the University of California at Berkeley, and ETLA, The Research Institute of the Finnish Economy.

Open Access This article is distributed under the terms of the Creative Commons Attribution Noncommercial License which permits any noncommercial use, distribution, and reproduction in any medium, provided the original author(s) and source are credited.

\section{References}

Aiginger K (2007) Industrial Policy: Past, Diversity, Future; Introduction to the Special Issue on the Future of Industrial Policy. J Ind Competition Trade 7(3/4):143-146. doi:10.1007/s10842-007-0023-9

Ali-Yrkkö J, Rouvinen P, Seppälä T, Ylä-Anttila P (2011) Who captures value in global supply chains? Case Nokia N95 Smartphone. Journal of Industry, Competition and Trade. doi:10.1007/s10842-0110107-4

Baldwin R (2006) Globalisation: The Great Unbundling(s). The Economic Council of Finland, Prime Minister's Office (http://www.vnk.fi/hankkeet/talousneuvosto/tyo-kokoukset/globalisaatioselvitys-92006/artikkelit/Baldwin_06-09-20.pdf), Helsinki

Crafts N (2004) Steam as a general purpose technology: a growth accounting perspective. Econ J 114 (495):338-351. doi:10.1111/j.1468-0297.2003.00200.x

Grossman GM, Rossi-Hansberg E (2008) Trading tasks: a simple theory of offshoring. Am Econ Rev 98 (5):1978-1997

Helpman E (1998) General purpose technologies and economic growth: introduction. In: Helpman E (ed) General purpose technologies and economic growth. MIT Press, Cambridge and London, pp 1-14

Jovanovic B, Rousseau PL (2005) General purpose technologies. In: Aghion P, Durlauf SN (eds) Handbook of economic growth, vol 1B. North-Holland, Amsterdam

Kenney M (2004) Introduction. In: Kenney M, Florida R (eds) Locationg global advantage: industry dynamics in the international economy. Stanford University Press, Stanford, pp 1-20 
Kenney M, Pon B (2011) Structuring the smartphone industry: is the mobile internet OS platform the key? Journal of Industry, Competition and Trade. doi:10.1007/s10842-011-0105-6

Kushida KE (2011) Leading without followers: how politics and market dynamics trapped innovations in Japan's domestic telecommunications sector. Journal of Industry, Competition and Trade. doi:10.1007/ s10842-011-0104-7

Kushida KE, Murray J, Zysman J (2011) Cloud computing and implications for public policy. Journal of Industry, Competition and Trade. doi:10.1007/s10842-011-0106-5

Watson BC (2011) Barcode empires: politics, digital technology, and comparative retail firm strategies. Journal of Industry, Competition and Trade. doi:10.1007/s10842-011-0109-2 